\title{
STORING SUNFLOWER SEEDS AND QUALITY LOSSES DURING STORAGE*
}

\section{Can Burak SISMAN, Lokman DELIBAS}

Trakya Univ. Tekirdag Agricultural Faculty, Farm Structure and Irrigation Dept.59030 Tekirdag, Turkey

Tel: +90 282 2931442, Fax: +90 282 2931454, e-mail: cbsisman@tu.tzf.edu.tr

Manuscript received: May 25, 2004; Reviewed: December 16, 2004; Accepted for publication: December 17, 2004

\section{ABSTRACT}

In this research, sunflower storage buildings in the Thrace region were examined. Influences of storage condition on product losses were investigated. According to the results of experiments in selected stores, the worst storage conditions and the most quality losses were determined in the concreate store, on the other hand the most suitable conditions and the least losses were determined in model store.

KEY WORDS: storage, sunflower, storage buildings, storage conditions, aeration 


\section{DETAILED ABSTRACT}

The aim of storage is to preserve properties of products and their freshness. If suitable storage conditions aren't supplied according to product variety, quality and quantity losses increase. Decreasing this losses is possible with providing suitable storage condition and storage management.

In this study, sunflower storage buildings in the Thrace region were examined. Influences of storage condition on product losses were investigated. The study was conducted in one of the Trace Union's reinforced concrete store, temporary store and a model store having aeration system built specificly for this research in Tekirdag Agricultural Faculty's area. Temperature and relative humidity of the sunflower mass as storage conditions in the stores and moisture content due to its effect on quality parameters, oil content and free fatty acids contents as quality parameters were monitored during the storage. According to the results of experiments in selected stores, the worst storage conditions and the most quality losses were determined in the concreate store, on the other hand the most suitable conditions and the least losses were determined in model store.

\section{INTIRODUCTION}

Food which is to be both vegetable and animal origin undergoes some changes because of its sutructures when kept for long time. Therefore, storage or keeping food and food's raw materials without spoiling is vital. The aim of storage is to preserve properties of products and their freshness until marketing or consuming. Storage is done to maintaine harvesting quality of products not to improve it [1].

The losses of farm crops because of spoilage, sprouting, warming, insect and mold damages cost millions dollars per year during harvesting, carrying and storing. These losses and spoilage during storage can only be reduced by suitable storage and storage management and this leads to contribute to country economy [2].

Turkey is $9^{\text {th }}$ largest sunflower producer in the world with the average of 843000 ton the 578000 ha farm area. However this production covers $50 \%$ of sunflower requirement of Turkey and the remaining part is important $60 \%$ of sunflower production in Turkey $(500000 \mathrm{t})$ is produced in Thrace region [3]. On the other hand, because of restricted storage possibility in this region and using temporary stores widespreadly leads to quality losses of approximately 10 million US \$ per year [4].

The objective of this study is to investigate the present state of different sunflower storage buildings in Thrace Region, to identify the reason effective for the losses during the storages and to suggeste suitable storage conditions and features of sunflower storage buildings for the Region to minimize the losses.

\section{MATERIAL}

The study was carried out in one of the Thrace Union's, which is the state oil production company in Tekirdag, reinforced concrete store (flat store), Yağcı Village temporary store and a model store built specifically for this research in the Agricultural Faculty's area. Sunflower seeds were collected from these stores every month regularly during the three months storage period started from September 2001 and all analysis were done on these samples.

Tekirdag concrete store had total $1526 \mathrm{t}$ capacity with 16 $\mathrm{m}$ in width, $48 \mathrm{~m}$ in length, $6.4 \mathrm{~m}$ in side wall height and $10.4 \mathrm{~m}$ in ridge pole height. It was built South-North direction and in the shape of joined (threepal). Sunflower seeds harvested in 2001 with $7 \%$ moisture content and 3 $\%$ foreign material were placed in this store.

Temporary sunflower store in Yagc village had $1642 \mathrm{t}$ capacity and was settled up in East-West direction. This store was $180 \mathrm{~m}$ length, $10 \mathrm{~m}$ width and $3.6 \mathrm{~m}$ height. During its consturuction, first soil was compressed, drainage ditches were opened at side of the store and a nylon canvas was spread over the soil. $1.3 \mathrm{~m}$ height store walls were formed by stacking sacks ful of sunflower one on the top of the other. Sunflowers were heaped between the walls and covered with canvas and then it was tied firmly. Sunflower seeds harvested in 2001 having $6 \%$ moisture content and $3 \%$ foreign material were placed in this store.

A model store having an aeration system and $2 \mathrm{~m}^{3}$ capacity was built and the quality losses in this store were compared to the losses occurred in the existing stores in the region. The floor of the model store was concrete, walls were bricks and plaster. The aeration in the store was done using two ducts on the floor having $1.5 \times 0.1 \mathrm{~m}$ cross sectional area as suggested by Hellevang [5] and Proctor [6]. Air flow rate was supplied with a fan having $0.3 \mathrm{~m}^{3} / \mathrm{min}$ per $2 \mathrm{~m}^{3}$ crop and having $0.2 \mathrm{~m}$ diameter as proposed by Hall [2], Hellevang [5], Cloud \& Morey [7], Bloome et al. [8], Hofman \& Hellevang [9], and Harner et al. [10]. The size of the open area in the roof was 0.75 $\mathrm{m}^{2}$ (cross sectional area) as recommended by Hellevang [5], Proctor [6] and Bloome et al. [8]. $830 \mathrm{~kg}$ sunflower having $6 \%$ moisture content and $3 \%$ foreign material was placed in this store. 


\section{METHODS}

Mass temperature and relative humidity as storage conditions and moisture content due to its effect on quality criteria, oil content and free fatty acidty as sunflower quality criteria were determined on the sample collected from each stores during the storage. $3 \times 4 \times 3$ factorial experimental design as randomized plot design was applied [11]. Factors in this design were the three stores, four locations and the three months storage period.

Measurements of mass temperature and humidity in the stores were recorded using digital humidity/ temperaturemeter instrument weekly as triple replicated at four different points of each stores as recommended by Harrier [12], Thompson \& Shelton [13], Noyes et al. [14] and Harner \& Hellevang [15]. Temperature and humidity measurements were done at two different points in the center and side of store and also at two different depths, at $25 \%$ and $75 \%$ of the mass depth.

Weather temperature and relative humidity were measured by a termohydrograph and these records regulated when to operate the aeration system in the model store. Aeration was operated as soon as the air temperature was $5^{\circ} \mathrm{C}$ cooler than that of the mass and was continued until the temperatures became equal. Aeration system was also shut when the relative humidity exceeded $75 \%$ and during the rainy period [5, 7, 12 and 15].

Sunflower samples were taken every month regularly in the stores to determine the quality losses occurred in the stores during storage period. The samples were taken in tree replications from the center and side of the stores and at two different depths, $25 \%$ and $75 \%$ of the mass depths according to Turkish Standarts no 163 related to Taking Sample from Oil Seed (Turkish Standard Institute, 1980) [16]. Partitioned hand probe was used for taking samples.

Analyzes of moisture content, oil content and free fatty acidty in the laboratory were done on the samples. Moistture contents were determined on basis of dry weight. To determined the oil contents Soxheled method (IUPAC method no: 1.122) was used [17]. Free fatty acidty was determined using titratable acidity in IUPAC method no: 2.201 [17].

The results obtained were evaluated using SPSS and MSTAT computer programs for Variance analysis and Duncan tests.

\section{RESULT AND DISCUSSIONS}

\section{Storage Conditions}

Changes in the average temperatures and humidities during the storage period were presented in Fig 3.1,
3.2 and 3.3 for concrete, temporary and model stores, respectively.

As seen in Fig 3.1, in general, mass temperature varied with the weather temperature. However, as expected, a quick response to weather temperature was observed in the sides and upper part of the mass in order to meet the heat losses from these parts [6, 9, 18, and 19].

A continous increase in the humidity of mass in this store from about $82 \%$ to $92 \%$ was recorded (Fig 3.1). This was attributed to the increase in the mass temperature causing to rise in the crop respiration and therefore more damp was released in to the mass [20]. The increase in the humidity more got to side of store and upper part of mass. The reason for the rise in the humidity in these parts is be cause of the moisture migration that is resulted from temperature differences in the store [1, 19, 20, and 21].

As shown Fig 3.2, generally, temperature of the crops that was put into the place at high temperature in the temporary store reduced. In this period, mass temperature increased as parallel to increasing weather temperature from time to time. In these months, especially temperature of sides and upper part of mass was more affected from weather temperature changes as explained by Hellevang [5], Harner et al. [10], Thompson \& Shelton [13] and Hellevang [19] and it reduced.

In generally, mass humidity in temporary store rose steadily and reached $94 \%$ except an uprupt change in the end of September. While the humidity rose in middle of the store, it reduced in the side of the store. This is becase of high mass temperature and respiration. An uprupt change in the end of September may be explained by heavy rains during that period. In the second month the storage, a relatively more rise in the humidity of the side and upper part of the store resulted from the moisture migration that was created by the temperature differences in the store as explained by Jones \& Shelton [1], Cloud \& Morey [7], Harner et al. [10], Thompson \& Shelton [13], Hellevang [19] and Hellevang [21].

Temperature of the crops in the model store (Fig. 3.3) decreased gradually from about $32{ }^{\circ} \mathrm{C}$ to $14{ }^{\circ} \mathrm{C}$ to wards the end of the storage. Because of aeration (total 193h), temperature differences occured between the zones in the store were not significant. Therefore moisture migration in the store in great extend was prevented $[1,5,7,10,19$ and 21]. When aeration was stopped, mass temperature rose, but it was decreased again with operating of aeration.

Mass humidity in the model store was reduced to $69 \%$ by aeration which is minimum value observed during the storage. After than, mass humidity rised untill $81 \%$ for not operating the aeration due to rainy. 
In this part, temperature and humidity values were evaluated statistically seperately, in order to determined differences between stores (Table 3.1, Table 3.2 and Table 3.3).

As seen in Table 3.1, the most suitable storage conditions with $25.28{ }^{\circ} \mathrm{C}$ temperature and $73.78 \%$ humidity was obtained in the model store and the most unfavorable conditions with $36.02{ }^{\circ} \mathrm{C}$ temperature and $86.77 \%$ humidity was obtained in concrete store.

These differences between stores clearly show the effect of aeration done in the model store. The temporary store is better than concrete store for short period of storages, because temporary store was quickly affected from decreasing weather temperature during the storage as expressed by Harner et al. [10], Brooker et al. [18] and Hellevang [22].

When the temperature of the zones with in the stores were compared (Table 3.2), variations between upper middle part and other zones of the mass for the model store, between side and middle zone for the temporary store and among all zones for the concrete store were observed. In the same way, when the zones of the mass were compared in terms of humidity, while there were not any differences between zones for the model store, statistically significant differences between side and middle zone of the temporary store and between lower middle zones and other zones in the concrete store were determined. According to these results, it may be concluded that moisture migration due to the temperature and humidity variations in the mass, could be prevented in the model store while it was not possible in the temporary and the concrete stores.

When the stores were compared in terms of storage period, a continuous decrease in the mass temperatures of the model and temporary store during the storage period was seen because of lower weather temperature. However in the concrete store the temperature increased during the first month and then increased until the end of the storage. Warming up in the concrete store in the first month is resulted from lack of aerating and crop respiration. While mass humidity decreased in the model store because of aerating in the first month, it raised for temporary and concrete stores.

\section{Sunflower Quality Criteria}

\section{Moisture Content}

Moisture content is one of the most important criteria effective on the losses during storage. Therefore, moisture contents of sunflower samples taken regularly from the stores were determined and changes in the moisture contents with time during the storage were presented in
Fig 3.4.

With the decreasing weather temperature from October, while the moisture content in the lower part of the mass decreased, it increased about $9.7 \%$ in the upper part of the mass in response to the moisture migration created by the temperature variations in the mass. Moisture content of the crop in the store exceeded $8 \%$ which was recommended level by Hofman \& Hellevang [9], Harrier [12], Brooker et al. [18], Hellevang [19] and Patterson [20].

Moisture contents in the temporary store continuously increased throughout the storage period. This increase was more in the upper part of the mass when compared with the bottom. Moisture content in the second month of the storage continued to increase and it especially raised more in the sides of the store. The highest moisture content during storage was determined as $9.2 \%$ in this zone. This was because of moisture migration. Moisture content in this store exceeded $8 \%$ suggested for safely storage by Hofman \& Hellevang [9], Harrier [12], Brooker et al. [18], Hellevang [19] and Patterson [20].

Unlike other stores, moisture contents of sunflowers in the model store decreased because the relative humidity of the fresh air entering into the store by ventilation was below $75 \%$. Moreover, the moisture accumulation due to the respiration was removed by ventilation.

The result of Duncan tests on moisture contents in the stores were given in Table 3.4. According to Duncan test (Table 3.4), while moisture content in the model store decreased by $0.075 \%$, it increased in the other stores and the highest increase was recorded in the temporary store by $0.902 \%$. Decreasing moisture content in the model store resulted from aeration.

When the zones in the stores were compeared, it was seen that the highest decrese in the moisture content was obseved in the model store in upper side of the mass and in side of store; on the other hand the highest increase in the concrete and temporary stores was in upper side of the mass.

End of the storage, moisture contents of model store decreased $0.16 \%$ and while it increased in concrete and temporary stores. Especialy in the temporary stores, moisture content increased by $2.04 \%$ because it was influenced much by the outside air condition of these stores $[10,22])$.

\section{Oil Content}

Changes of oil contents, which is the most important feature of sunflowers, was determined by analyzes that was regularly done on the samples taken from stores and changes in the oil contents with time were presented in Fig 3.5. 
Oil contents in the concrete store were continuously decreased during the storage. The oil content of $43.5 \%$ at the beginning decreased approximately $0.5 \%$. This loss in the first month was higher in the middle part of the store. This is because of high temperature and moisture content of the crops in these zones. In the second month of the storage, oil contents decreased $0.7 \%$ and $2.8 \%$ in middle of the store and in side of the store, respectively. This decrease was due to $9.7 \%$ moisture content in side of store suddenly.

Oil contents in temporary store were continuously decreased during the storage and in the first month, this decrease was $0.3 \%$. In the second month, oil content in the sides of the store and in the bottom of the mass reduced more. A considerable decrease in these zones was resulted from the high moisture content in the sides and high temperature in the bottom zones.

According to Fig 3.5, oil content in the model store continuously decreased during the storage, but relatively less losses occurred in this store when compaired with the others due to temperature and humidity which is lower than $8 \%$, suggested for a safe storage $[5,6,12$, 18 and 19].

Duncan tests done to compaire oil contents changes during the storage were given in Table 3.5, respectively. According to the Duncan test (Table 3.5), model store gave the best result with $0.271 \%$ decrease in the oil content and the worst result was obtained for concrete store with $0.889 \%$ decrease. The highest oil loss in the concrete store was caused by mass temperature and humidity in this store higer than other stores.

When the zones in stores were investigated, there were differences between the middle upper side zones of the mass and other zones in the model store and between all zones in the temporary and concrete stores. Because of being the same amount of oil losses between the zones in the model store statistically, it can be concluded that temperature and humidity distributions was homogeneous. A significant amount of oil losses in bottom zones of the temporary store was determined. Higher temperature in bottom zones of temporary store caused more lost in the oil content. In the concrete store, oil losses in the sides of the store were found to be more than that of the other zones because of higer temperature and moisture content within these zones.

Oil contents in all stores decreased during the storage. In the end of the storage, while the concrete store gave worst result with $2.167 \%$ oil losses, the model store gave best result with $0.52 \%$ losses.

\section{Free Fatty Acidty}

Free fatty acidity which affects losses occured during the refination was determined by analysis that was regularly done on the sample taken from the stores and changes in the free fatty acidity with time were presented in Fig 3.6.

Free fatty acidity of sunflowers in the stores continuously increased during the storage. In the concrete stores, free fatty acidity in sides of store and undersides of the mass were higher than in the middle of the store and in the upper side of the mass. High temperature and humidity in undersides of the mass caused to increase in the free fatty acidity. Nas et al. [23] explained that increase in the temperature and humidity caused to spoile of oil and increasing of free fatty acidity.

In the temporary store, free fatty acidity increased more in the upper part of the mass. Increased moisture content owning to the moisture migration in upper part of the mass caused to icreasing in the free fatty acidity in this zone. Acidity in the upper parts of mass increased by 0.55 $\%$.

The increase in the free fatty acidity in the model store was less than in the other stores. The increase in the acidity in the upper part of the mass near the walls was more than in the other zones. High temperature in this zone during the first month of the storage caused this increase in the acidity.

Duncan tests to determine the differences between the stores was given in Table 3.6 Among the stores, least acidity chang appeared in model store with $0.062 \%$ and this was fallowed by the temporary store with $0.075 \%$ and the concreta store with $0.215 \%$. Relatively higher temperature and humidity in the concrete store caused to more increase when compaired with the other stores in the acidity.

When the acidity differences among the zones in the stores were considered (Table 3.6), it can be seen that the acidity change in the upper part of the mass near the walls of model store differred from the other zones and for temporay store, change in the sides of the store deviated from the midlle and for the concrete store, changes in whole zones varied from each other. The results imply that while the homogenous storage conditions in the model store were created, worst storage condition prevails in the concrete store.

The least free fatty acidity in the stores during the storage was determined at beginning of the storage and acidity continuously increased in all stores. In the end of the storage, the free fatty acidity increased and reached 0.13 $\%$ for the model store, $0.15 \%$ for the temporary store and $0.41 \%$ for the concrete store. Acidity increases in the concrete store was three times more than the other stores. 


\section{Can Burak SISMAN, Lokman DELIBAS}

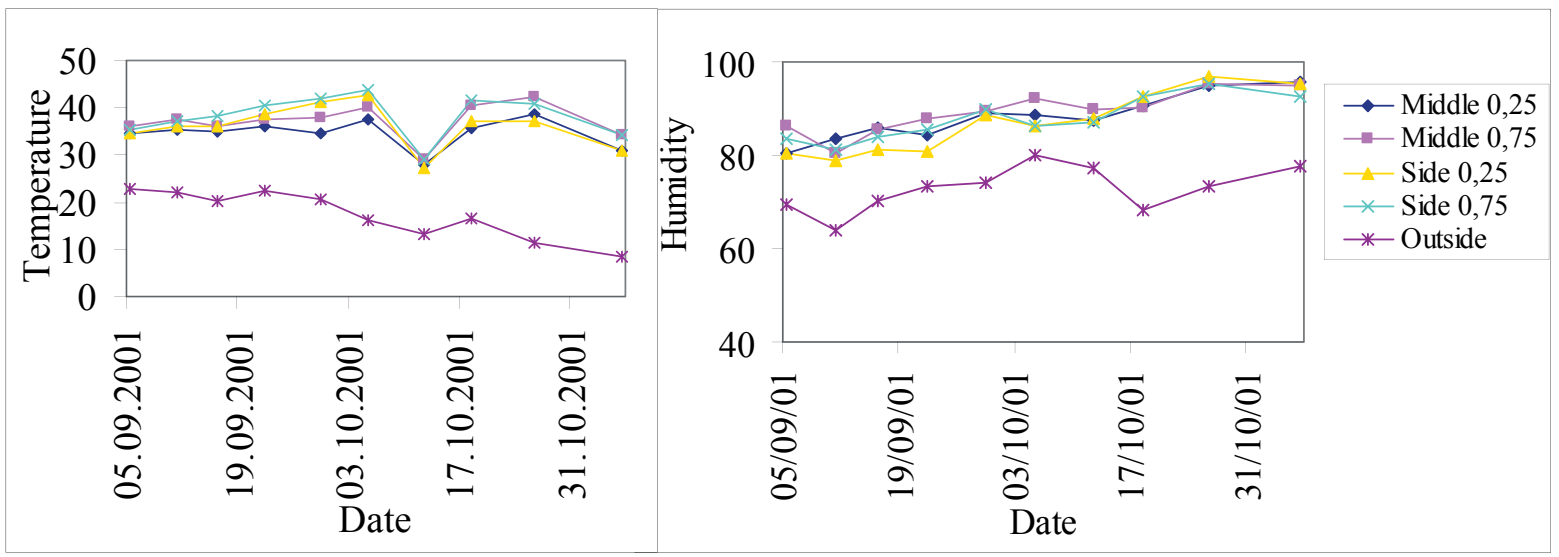

Figure 3.1. Changes in the temperature and humidity in the concrete store during the storages

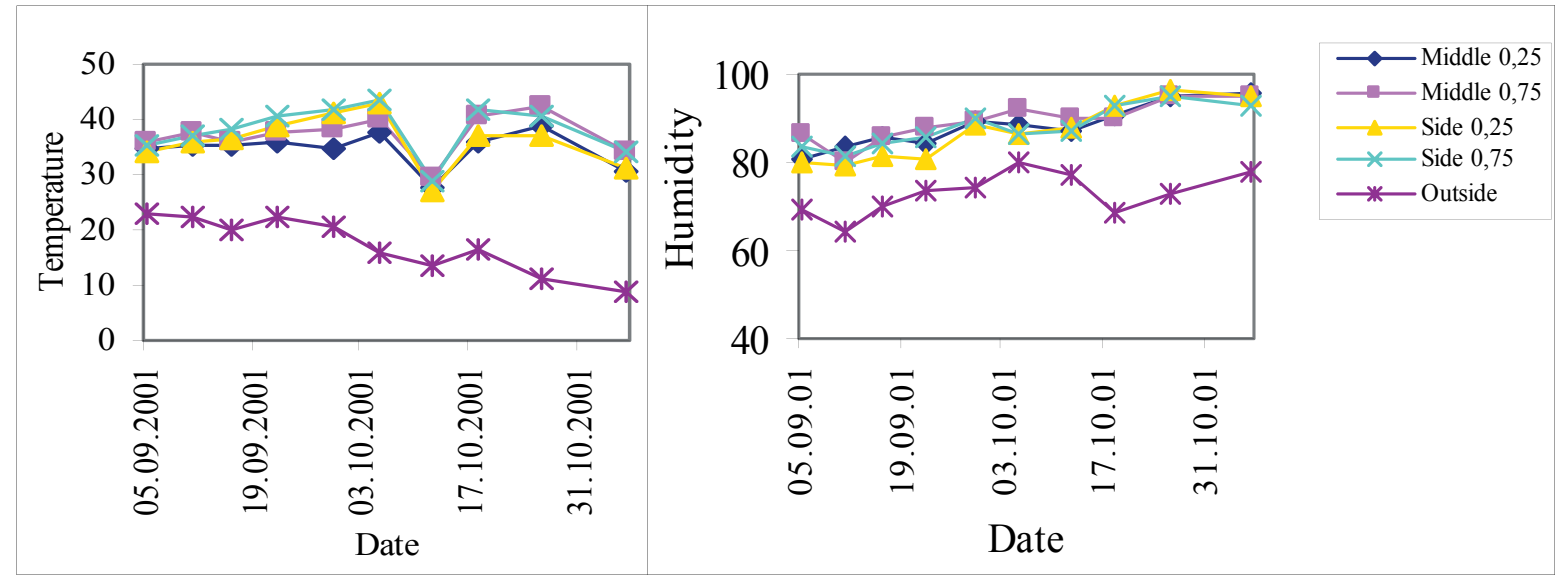

Figure 3.2. Changes in the temperatures and humidities in the temporary store during the storages

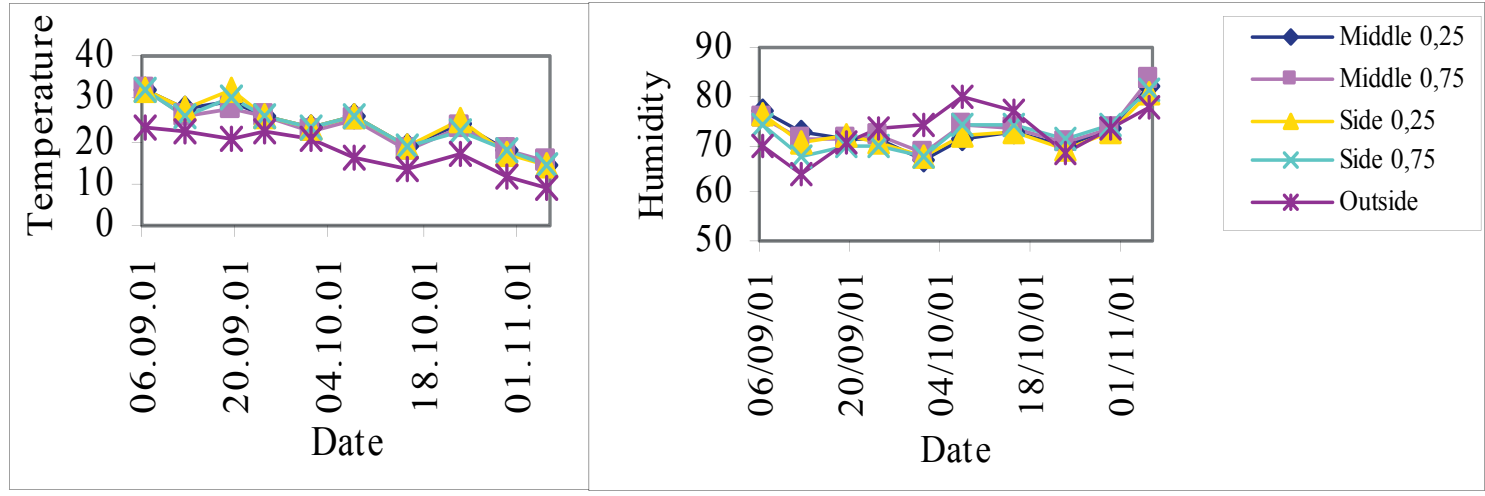

Figure 3.3. Changes in the temperature and humidity with time in the model store 


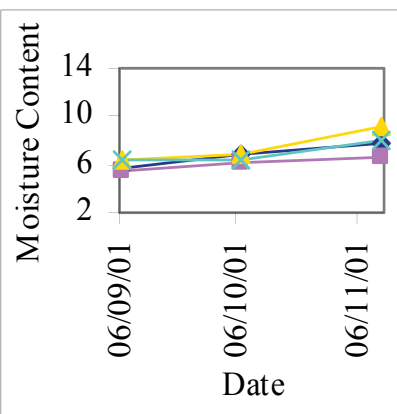

Concrete Store

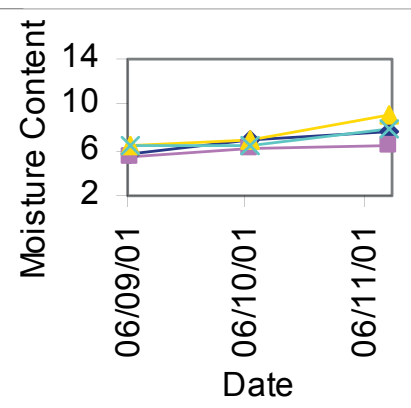

Temporary

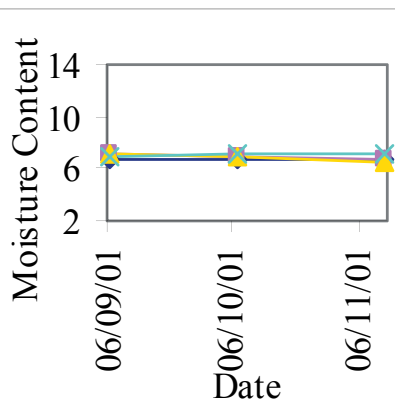

Model

Figure 3.4. Change in moisture content of sunflower samples.

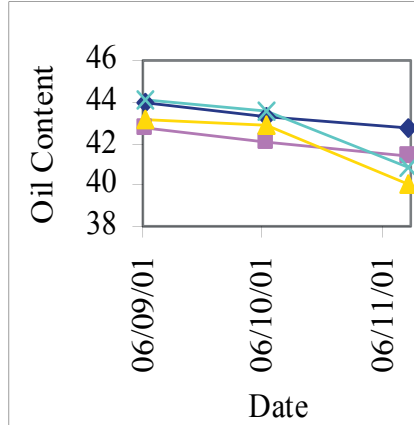

Concrete

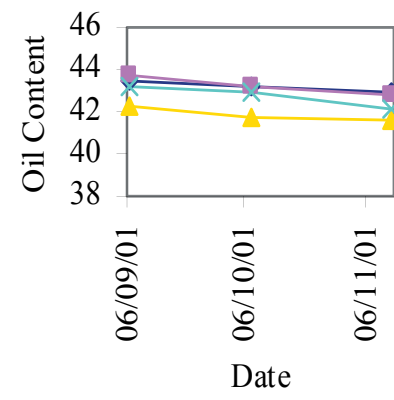

Temporary

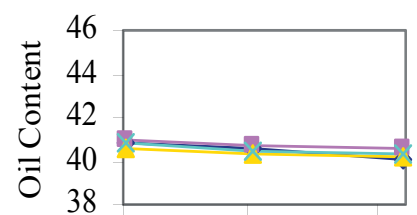

$\multimap$ Middle 0.25

-r Middle 0.75

Side 0.25

Side 0.75

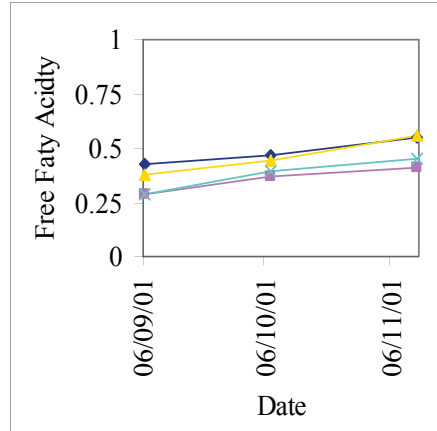

Concrete

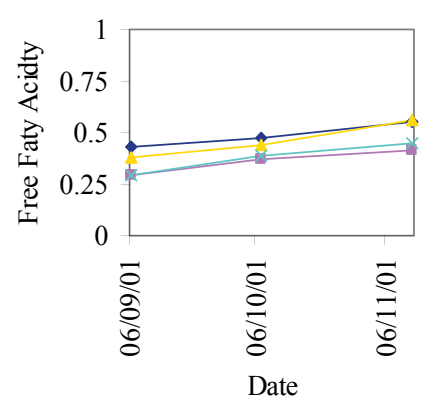

Temporary

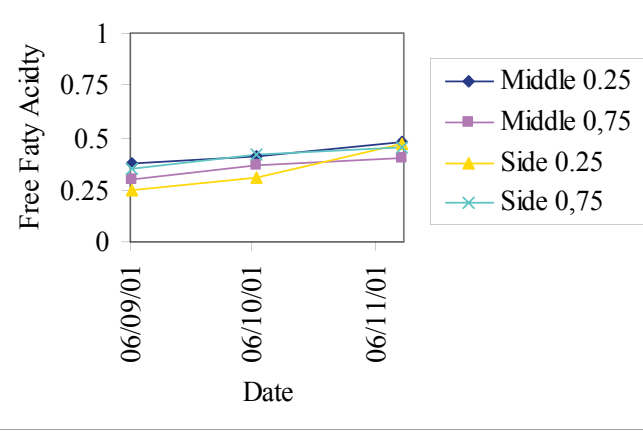

Model

Figure 3.6. Changing of free fatty acidity of sunflower samples 


\section{Can Burak SISMAN, Lokman DELIBAS}

Table 3.1. Duncan test results related to storage conditions in the stores

\begin{tabular}{llccc}
\hline Store & Store & Avarage & $\begin{array}{c}\text { Standard } \\
\text { Eror }\end{array}$ & $\begin{array}{c}\text { Duncan* } \\
0.01\end{array}$ \\
\hline Temparature & Model & 25.280 & 0.098 & $\mathrm{~A}$ \\
& Temporary & 29.269 & 0.098 & $\mathrm{~B}$ \\
\multirow{3}{*}{ Mass } & Concrete & 36.023 & 0.098 & $\mathrm{C}$ \\
Humidity & Model & 73.784 & 0.184 & $\mathrm{~A}$ \\
& Temporary & 81.226 & 0.184 & $\mathrm{~B}$ \\
& Concrete & 86.774 & 0.184 & $\mathrm{C}$ \\
\hline
\end{tabular}

* Significant at 0.01 confidence level

Table 3.2. Duncan test results related to storage conditions in the stores

\begin{tabular}{|c|c|c|c|c|c|}
\hline Store *Zone & Store & Zone & Avarage & $\begin{array}{l}\text { Standard } \\
\text { Eror }\end{array}$ & $\begin{array}{c}\text { Duncan* } \\
0.01\end{array}$ \\
\hline \multirow{10}{*}{ Sicaklık } & \multirow{3}{*}{ Model } & Midlle 0.25 & 25.603 & 0.196 & $\bar{B}$ \\
\hline & & Midlle 0.75 & 25.223 & 0.196 & $\mathrm{AB}$ \\
\hline & & Side 0.25 & 24.790 & 0.196 & A \\
\hline & \multirow{5}{*}{ Temporary } & Side 0.75 & 25.503 & 0.196 & $\mathrm{AB}$ \\
\hline & & Midlle 0.25 & 30.520 & 0.196 & $\mathrm{D}$ \\
\hline & & Midlle 0.75 & 30.630 & 0.196 & $\mathrm{D}$ \\
\hline & & Side 0.25 & 28.166 & 0.196 & $\mathrm{C}$ \\
\hline & & Side 0.75 & 27.760 & 0.196 & $\mathrm{C}$ \\
\hline & \multirow{3}{*}{ Concrete } & Midlle 0.25 & 34.537 & 0.196 & $\mathrm{E}$ \\
\hline & & Midlle 0.75 & 36.807 & 0.196 & G \\
\hline \multirow{14}{*}{ Mass Humidity } & & Side 0.25 & 35.473 & 0.196 & F \\
\hline & \multirow{5}{*}{ Model } & Side 0.75 & 37.273 & 0.196 & G \\
\hline & & Midlle 0.25 & 74.120 & 0.369 & A \\
\hline & & Midlle 0.75 & 74.133 & 0.369 & A \\
\hline & & Side 0.25 & 73.577 & 0.369 & A \\
\hline & & Side 0.75 & 73.307 & 0.369 & A \\
\hline & \multirow{3}{*}{ Temporary } & Midlle 0.25 & 81.218 & 0.369 & $\mathrm{BC}$ \\
\hline & & Midlle 0.75 & 82.073 & 0.369 & $\mathrm{C}$ \\
\hline & & Side 0.25 & 80.233 & 0.369 & B \\
\hline & \multirow{5}{*}{ Concrete } & Side 0.75 & 81.380 & 0.369 & $\mathrm{BC}$ \\
\hline & & Midlle 0.25 & 86.037 & 0.369 & $\mathrm{D}$ \\
\hline & & Midlle 0.75 & 88.600 & 0.369 & $\mathrm{E}$ \\
\hline & & Side 0.25 & 85.563 & 0.369 & $\mathrm{D}$ \\
\hline & & Side 0.75 & 86.897 & 0.369 & $\mathrm{D}$ \\
\hline
\end{tabular}

\footnotetext{
* Significant at 0.01 confidence level
} 
Table 3.3. Duncan test results related to storage conditions in the stores

\begin{tabular}{|c|c|c|c|c|c|}
\hline Store*Period & Store & Period & Avarage & $\begin{array}{l}\text { Standard } \\
\text { Eror }\end{array}$ & $\begin{array}{l}\text { Duncan* } \\
0.01\end{array}$ \\
\hline \multirow{9}{*}{ Temperature } & \multirow[t]{3}{*}{ Model } & September & 32.213 & 0.170 & $\mathrm{D}$ \\
\hline & & October & 26.140 & 0.170 & $\mathrm{C}$ \\
\hline & & November & 17.488 & 0.170 & $\mathrm{~A}$ \\
\hline & \multirow[t]{3}{*}{ Temporary } & September & 35.625 & 0.170 & $\mathrm{~F}$ \\
\hline & & October & 31.820 & 0.170 & $\mathrm{D}$ \\
\hline & & November & 20.362 & 0.170 & B \\
\hline & \multirow[t]{3}{*}{ Concrete } & September & 35.113 & 0.170 & $\mathrm{EF}$ \\
\hline & & October & 38.165 & 0.170 & $\mathrm{G}$ \\
\hline & & November & 34.790 & 0.170 & $\mathrm{E}$ \\
\hline \multirow{9}{*}{ Mass Humidity } & \multirow[t]{3}{*}{ Model } & September & 75.738 & 0.319 & $\mathrm{C}$ \\
\hline & & October & 70.482 & 0.319 & A \\
\hline & & November & 75.133 & 0.319 & $\mathrm{BC}$ \\
\hline & \multirow[t]{3}{*}{ Temporary } & September & 74.125 & 0.319 & B \\
\hline & & October & 79.843 & 0.319 & $\mathrm{D}$ \\
\hline & & November & 89.710 & 0.319 & $\mathrm{G}$ \\
\hline & \multirow[t]{3}{*}{ Concrete } & September & 82.550 & 0.319 & $\mathrm{E}$ \\
\hline & & October & 85.540 & 0.319 & $\mathrm{~F}$ \\
\hline & & November & 92.232 & 0.319 & $\mathrm{H}$ \\
\hline
\end{tabular}

* Significant at 0.01 confidence level

Table 3.4. Duncan test results of changing moisture content in the stores

\begin{tabular}{|c|c|c|c|c|c|}
\hline Store & Store & & Avarage & $\begin{array}{l}\text { Standard } \\
\text { Eror }\end{array}$ & $\begin{array}{l}\text { Duncan* } \\
0.01\end{array}$ \\
\hline Moisture & Model & & -0.075 & 0.005 & $\mathrm{~A}$ \\
\hline Content & Temporary & & 0.902 & 0.005 & $\mathrm{C}$ \\
\hline Changing & Concrete & & 0.563 & 0.005 & $\mathrm{~B}$ \\
\hline \multirow[t]{6}{*}{ Store $*$ Zone } & \multirow[t]{2}{*}{ Store } & Zone & & & \\
\hline & & Midlle 0.25 & -0.086 & 0.011 & $\mathrm{C}$ \\
\hline & \multirow[t]{4}{*}{ Model } & Midlle 0.75 & -0.167 & 0.011 & B \\
\hline & & Side 0.25 & -0.223 & 0.011 & A \\
\hline & & Side 0.75 & 0.173 & 0.011 & $\mathrm{D}$ \\
\hline & & Midlle 0.25 & 1.140 & 0.011 & $\mathrm{I}$ \\
\hline \multirow{7}{*}{$\begin{array}{l}\text { Moisture } \\
\text { Content } \\
\text { Changing }\end{array}$} & \multirow{4}{*}{ Temporary } & Midlle 0.75 & 0.730 & 0.011 & $\mathrm{H}$ \\
\hline & & Side 0.25 & 1.177 & 0.011 & $\mathrm{I}$ \\
\hline & & Side 0.75 & 0.563 & 0.011 & $\mathrm{G}$ \\
\hline & & Midlle 0.25 & 0.460 & 0.011 & $\mathrm{~F}$ \\
\hline & \multirow{3}{*}{ Concrete } & Midlle 0.75 & 0.187 & 0.011 & $\mathrm{D}$ \\
\hline & & Side 0.25 & 1.357 & 0.011 & $\mathrm{~J}$ \\
\hline & & Side 0.75 & 0.247 & 0.011 & $\mathrm{E}$ \\
\hline \multirow[t]{5}{*}{ Store*Period } & Store & Period & & & \\
\hline & \multirow[t]{4}{*}{ Model } & September & 0 & 0.009 & $\mathrm{C}$ \\
\hline & & October & -0.062 & 0.009 & $\mathrm{~B}$ \\
\hline & & November & -0.165 & 0.009 & A \\
\hline & & September & 0 & 0.009 & $\mathrm{C}$ \\
\hline \multirow{5}{*}{$\begin{array}{l}\text { Moisture } \\
\text { Content } \\
\text { Changing }\end{array}$} & \multirow{3}{*}{ Temporary } & October & 0.660 & 0.009 & $\mathrm{D}$ \\
\hline & & November & 2.047 & 0.009 & $\mathrm{~F}$ \\
\hline & & September & 0 & 0.009 & $\mathrm{C}$ \\
\hline & \multirow{2}{*}{ Concrete } & October & 0.647 & 0.009 & $\mathrm{D}$ \\
\hline & & November & 1.040 & 0.009 & $\mathrm{E}$ \\
\hline
\end{tabular}

* Significant at 0.01 confidence level 
Table 3.5. Duncan test results relating to changing oil content in the stores

\begin{tabular}{|c|c|c|c|c|c|}
\hline Store & Store & & Avarage & $\begin{array}{l}\text { Standard } \\
\text { Eror }\end{array}$ & $\begin{array}{l}\text { Duncan* } \\
0.01\end{array}$ \\
\hline Oil Content & Model & & -0.271 & 0.007 & $\mathrm{~A}$ \\
\hline Changing & Temporary & & -0.387 & 0.007 & B \\
\hline \multirow{5}{*}{ Store *Zone } & Concrete & 7 one & -0.889 & 0.007 & $\mathrm{C}$ \\
\hline & & $\begin{array}{l}\text { Zone } \\
\text { Midlle } 0.25\end{array}$ & -0.350 & 0.013 & B \\
\hline & Model & Midlle 0.75 & -0.217 & 0.013 & $\mathrm{~A}$ \\
\hline & & Side 0.75 & -0.267 & 0.013 & A \\
\hline & & Midlle 0.25 & -0.217 & 0.013 & A \\
\hline \multirow{6}{*}{$\begin{array}{l}\text { Oil Content } \\
\text { Changing }\end{array}$} & Temporary & Midlle 0.75 & -0.483 & 0.013 & D \\
\hline & & Side 0.25 & -0.400 & 0.013 & $\mathrm{C}$ \\
\hline & & Side 0.75 & -0.450 & 0.013 & D \\
\hline & & Midlle 0.25 & -0.567 & 0.013 & $\mathrm{E}$ \\
\hline & Concrete & Midlle 0.75 & -0.667 & 0.013 & $\mathrm{~F}$ \\
\hline & & Side 0.75 & -1.189 & $\begin{array}{l}0.013 \\
0.013\end{array}$ & $\mathrm{H}$ \\
\hline \multirow[t]{5}{*}{ Store*Period } & Store & Period & & & \\
\hline & Model & September & 0 & 0.011 & A \\
\hline & & October & -0.287 & 0.011 & B \\
\hline & & November & -0.525 & 0.011 & D \\
\hline & & September & 0 & 0.011 & A \\
\hline \multirow{5}{*}{$\begin{array}{l}\text { Moisture } \\
\text { Content } \\
\text { Changing }\end{array}$} & Temnorary & October & -0.375 & 0.011 & $\mathrm{C}$ \\
\hline & 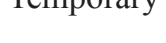 & November & -0.787 & 0.011 & $\mathrm{E}$ \\
\hline & & September & 0 & 0.011 & A \\
\hline & Concrete & October & -0.500 & 0.011 & D \\
\hline & COALICte & November & -2.167 & 0.011 & $\mathrm{~F}$ \\
\hline
\end{tabular}

* Significant at 0.01 confidence level

Table 3.6. Duncan test results relating to changing free fatty acidity in the stores

\begin{tabular}{|c|c|c|c|c|c|}
\hline Store & Store & & Avarage & $\begin{array}{l}\text { Standard } \\
\text { Eror }\end{array}$ & $\begin{array}{c}\text { Duncan* } \\
0.01\end{array}$ \\
\hline Acidity & Model & & 0.062 & 0.003 & $\mathrm{~A}$ \\
\hline Changing & Temporary & & 0.075 & 0.003 & B \\
\hline & Concrete & & 0.215 & 0.003 & $\mathrm{C}$ \\
\hline Store *Zone & Store & $\begin{array}{c}\text { Zone } \\
\text { Midlle } 0.25\end{array}$ & 0.043 & 0.006 & A \\
\hline $\begin{array}{l}\text { Acidity } \\
\text { Changing }\end{array}$ & Temporary & $\begin{array}{l}\text { Midlle } 0.75 \\
\text { Side } 0.25 \\
\text { Side } 0.75 \\
\text { Midlle } 0.25 \\
\text { Midlle } 0.75 \\
\text { Side } 0.25 \\
\text { Side } 0.75 \\
\text { Midlle } 0.25 \\
\text { Midlle } 0.75 \\
\text { Side } 0.25 \\
\text { Side } 0.75\end{array}$ & $\begin{array}{l}0.056 \\
0.093 \\
0.056 \\
0.066 \\
0.066 \\
0.080 \\
0.086 \\
0.147 \\
0.180 \\
0.253 \\
0.280\end{array}$ & $\begin{array}{l}0.006 \\
0.006 \\
0.006 \\
0.006 \\
0.006 \\
0.006 \\
0.006 \\
0.006 \\
0.006 \\
0.006 \\
0.006\end{array}$ & $\begin{array}{c}\text { AB } \\
\text { D } \\
\text { AB } \\
\text { ABC } \\
\text { ABC } \\
\text { BCD } \\
\text { CD } \\
\text { E } \\
\text { F } \\
\text { G } \\
\text { H }\end{array}$ \\
\hline Store*Period & Store & Period & & & \\
\hline $\begin{array}{l}\text { Acidity } \\
\text { Changing }\end{array}$ & $\begin{array}{l}\text { Temporary } \\
\text { Concrete }\end{array}$ & $\begin{array}{l}\text { September } \\
\text { October } \\
\text { November } \\
\text { September } \\
\text { October } \\
\text { November } \\
\text { September } \\
\text { October } \\
\text { November }\end{array}$ & $\begin{array}{c}0 \\
0.057 \\
0.130 \\
0 \\
0.075 \\
0.150 \\
0 \\
0.228 \\
0.417 \\
\end{array}$ & $\begin{array}{l}0.006 \\
0.006 \\
0.006 \\
0.006 \\
0.006 \\
0.006 \\
0.006 \\
0.006 \\
0.006 \\
\end{array}$ & $\begin{array}{l}\text { A } \\
\text { B } \\
\text { C } \\
\text { A } \\
\text { B } \\
\text { C } \\
\text { A } \\
\text { D } \\
\text { E }\end{array}$ \\
\hline
\end{tabular}

* Significant at 0.01 confidence level 


\section{CONCLUSION}

In this study conducted in the Thrace Region, influances of storage conditions on the quality losses occurred during storage of different storage buildings used for sunflower was investigation. According to the results of experiments in the selected stores, the worst storage conditions and the highest quality losses were determined in the concreate store, on the otherhand the most suitable conditions and the least losses were determined in the model store.

Creating suitable storage conditions to reduced losses in the concreate store which was recomended for sunflower storage in the previous study by Gaytancioglu [4] is not possible for the present situation. The biggest problem in this store may be prevented by increasing temperature and humidity in the store due to lack of aeration and increase in sutructural spoilages in the crop and losses created by insects.

Althougth results of temporary store was better than concreate store, in the temporary store, recommended suitable storage conditions is difficult to achieve and to maintain sunflowers quality features [12, 19, 22 and 24]. Temperature differences and moisture migration in the store were not prevented because the store was quickly affected by the outside conditions and rain entering into the store during rainy periods.

Storage conditions in the model store were kept under the $17{ }^{\circ} \mathrm{C}$ temperature and $75 \%$ relative humidity which were proposed for safe storage during autumn [1, 7, 13, 19 and 21]. Maintaining suitable storage conditions decreased the sunflower quality losses and losses in the controlled store was less than in the other stores.

Points that should be taken into consideration for sunflower storage were given as below:

Temporary storage widespreadly used in The Thrace region because of low construction and operating costs can be used for durations less then five month in Autumm when the weather temperature decreases continuously. However these stores must be unloaded before Sipring while weather temperature increases. These stores should not be used in the districts having much rain.

Present concrete stores in this region must be improved and first of all aeration system must be constructed. Aeration system which will be established in the concrete stores is founded easily with fans located on short side wall in the store and perforated ducts setteled on floor. Fan capacity, air velocity, cross sectional aeria of ducts and duct arrangement, size of open aeria in the roof, how much and when will be done aeration are important.

Cross sectional area of ducts and capacity of selected fans are detemined depending on store capacity and airflow rate must be supplied minimum $0.08 \mathrm{~m}^{3} / \mathrm{min}$ and maximum $0.8 \mathrm{~m}^{3} / \mathrm{min}$ for each cubic meter crop [7, 8, 9, 19 and 22]. Cross sectional area of ducts and perforated surface area should carry to this airflow rate. Air velocity in the ducts must be $0.2-10 \mathrm{~m} / \mathrm{s}$. Fans must place on walls to dominating wind direction for pressure fans and place on walls to accorss dominating wind direction for sucking fans.

Especially aeration system should be operated in autumm and spring months and mass temperature must be keep at $17-18{ }^{\circ} \mathrm{C}$ during this month and $0-5^{\circ} \mathrm{C}$ in winter $[12,19$, 22 , and 24]. Aeration system in the winter should be run periodically for a day or two during good weather when the outside temperature is near the temperature of the crops. Aerating of sunflower storage for Thrace region is adequate 200-210 h for autumm, 140-150 h for sipring.

Time of aeration must be determined according to the temperature measturement in the store. When regional or completely warming occure in the store, aeration system must be operate and mass must bu cooled. Temperature measturement in the store must be done as weekly in spring and monthly in winter for different zones and depths. When relative humidity of outside air is higer then $75 \%$, aeration must be closed and especially fans and chimneys must be covered on rainy days.

Maximum moisture content for storage of sunflowers is less then $9 \%$ for storage period shorter then six mounth and $8 \%$ for storage period longer then six mounth $[2,9$, $12,15,18,19,20$ and 22].

\section{REFERENCES}

[1] Jones D; Shelton P (1994). Management to Maintain Stored Grain Quality. Nebraska State Unv. Cooperative Extension Service, Institute of Agriculture and Natural Researces, G 94-1199-A, USA.

[2] Hall C W (1980). Drying and Storage of Agricultural Crops. The AVI Publishing Company Inc. ISBN 0-87055-364-X, USA.

[3] Anonymous (2002). Tarımsal Yapı (Üretim, Fiyat, Değer) 2000. T.C. Başbakanlık Devlet İstatistik Enstitüsü, Yayın No: 2547, Ankara.

[4] Gaytancioglu O (1999). Ayçiçeğinde Uygulanan Tarım Politikaları ve Depolamadan Doğan Ürün Kayıplarının Ekonomik Analizi. Yayınlanmamış.

[5] Hellevang K J (1990). Crop Storage Management. NDSU. Extension Service, ND 58105-AE-791, North Dakota, USA.

[6] Proctor D L (1994). Grain Storage Techniques Evolution and Trends in Developing Countries. FAO Agricultural Service Bulletin No 109, ISBN 92-5- 


\section{6-7,Roma.}

[7] Cloud H A; Morey R V (1991), Management of Stored Grain with Aeration, University of

Minnesota. Collage of Agricultural Food and Enviromental Science, FO 1327-GO, USA.

[8] Bloome P; Brusewitz G; Harp S (1995). Aeration and Cooling of Stored Grain. Oklahoma State Unv. Cooperative Extension Service, Division of Agricultural Science and Natural Resource, F-1101, Oklahoma.

[9] Hofman V L; Hellewang K J (1997). Harvesting Drying and Storage of Sunflower. Sunflower Technology and Production, American Society of Agronomy, Soil Science Society of American, Agronomy Monograph No 35, Madison,USA.

[10] Harner J P; Herrman T J; Reed C (1998). Temporary Grain Storage Considerations. Kansas State Unv. Agricultural Experiment Station and Cooperative Extension Service, MF 2362, Kansas.

[11] Soysal M İ (2000). Biometrinin Prensipleri. T.Ü. Tekirdağ Ziraat Fak. Yayın No: 74, Tekirdağ.

[12] Harrier J P (1987). Drying and Storing Sunflowers. Kansas State Unv. Cooperative Extension Service, Ag. Facts 158, Kansas.

[13] Thompson T L; Shelton D P (1993). Aeration of Stored Grain. Nort Dakota State Unv. Extension Service, G84-692, USA.

[14] Noyes R T; Clary B L; Cuperus G W (1998). Maintaining Quality of Stored Grain by Aeration. Oklahoma State Unv. Extension Service Division of Agricultural Science and Natural Resources, USA.

[15] Harner J P; Hellevang K (1999). High Plains
Sunflower Production Handbook. Kansas State Unv. Agricultural Experiment Station and Extension Service, MF 2384

[16] Ekmeklier H Y; Geçit H H (1986). Tarla Ürünleri Standardizasyonu ve Depolanması Uygulama Klavuzu. Ankara Ünv. Ziraat Fakültesi Yayınları No: 989, Ankara.

[17] Anonymous (1987). International Union for Pure and Applied Chemistry, Standard Methods of Analysis for the Analysis of Oil. Fats and Derivatives, $7^{\text {th }}$. End., Blacwell, Jevent Publishers, Oxford.

[18] Brooker D B; Arkema F B; Hall C W (1992). Drying and Storage of Grains and Oilseeds. An AVI Book, Published by Van Nostrand Reinhold, ISBN 0442-20515-5, New York

[19] Hellevang K J (2000). Storing Wet Sunflower. Irrigator's Workshops, Bismarck Radisson Inn. 4 Decenber 2000.

[20] Patterson H B W (1989). Handiling and Storage of Oilseed, Oils, Fats and Meal. Elsevier Applied Science, 294 p., NewYork.

[21] Hellevang K J (1995), Grain Moisture Content Effects and Management. NDSU. Extension Service AE-905, North Dakota.

[22] Hellevang K J (1998). Temporary Storage of Sunflower Seed. The Sunflower Magazine, Septenber, National Sunflower Association.

[23] Nas S; Gökalp H Y; Ünsal M (1998). Bitkisel Yağ Teknolojisi. Pamukkale Ünv. Mühendislik Fak. Ders Kitapları Yayın No 005, 329s, Denizli.

[24] Anonymous (1995). Drying and Storage Sunflower Production. NDSU Extension Service, Agricultural Experiment Station, EB 25, USA. 